\title{
Dilek Durukan
}

English Language Instructor

BA in English Language and Literature

Usak University

ORCID ID 0000-0002-6082-6192

dilek.durukan@usak.edu.tr

\author{
Ayhan Kahraman \\ Professor \\ Kütahya Dumlupınar University \\ Kütahya, Turkey \\ ORCID ID 0000-0002-3410-6351 \\ ayhan.kahraman@dpu.edu.tr
}

\section{PERCEPTIONS OF TURKISH SCHOOL TEACHERS ON THE USE OF MOTHER TONGUE IN EFL CLASSES}

\begin{abstract}
The article focuses on the research into the opinions of Turkish school teachers whether the mother tongue (L1) should be included or excluded in the foreign language classes. The problem under study has been debated by researchers and there is no consensus on this controversial issue. It is stated that most of the studies are conducted on the tertiary level, and there are very few ones on the primary \& secondary levels. Therefore, this study explores the perspectives of English teachers working in primary schools in comparison to high schools affiliated with Turkish national education. It also investigates for which language skills both of those groups find the use of mother tongue (Turkish) relatively effective and their justification behind the use of L1 in their classes in which English is taught as a foreign language. A total of 30 primary and 30 high school teachers working in Usak (Turkey) participated the study voluntarily. The study has employed mixed-method and data were collected through a questionnaire developed by Kuru and Tekin (2019). Moreover, semi structured interviews were conducted to obtain qualitative data with randomly selected primary school (8) and high school teachers (8). By means of the Statistical Package for Social Sciences (SPSS), descriptive statistics were conducted and qualitative data were analyzed thematically. Findings of the quantitative data indicated that majority of both primary and high school teachers support the use of mother tongue in English as a Foreign Language (EFL) classes. Additionally, there is no significance difference between the perceptions of primary school and high school teachers regarding the use of L1. Finally, results of the qualitative data advocate the findings of the quantitative data.
\end{abstract}

Keywords: mother tongue; primary school teachers; high school teachers; perceptions; semi structured interviews.

\section{INTRODUCTION}

Language is one of the most significant components that distinguish humans from other living things. Communication based interactions are vital to human being, and therefore, knowledge of language is one of the most essential segments that form the basis of the learning process. According to Bloomfield (1956) the language plays an important role in our life. For years, depending on the researches on the second language acquisition (SLA), use of mother tongue (L1) has been as either helpful tool or an obstacle for the second language (L2) learning process. Constant changes in the methodologies of language teaching are mostly shaped by the learners' needs and these changes reflects "a shift from transmission, product-oriented theories to constructivist, process-oriented theories of learning, teaching, and teacher learning" (Crandall, 2000, p. 34-35).

(C) Dilek Durukan, Ayhan Kahraman. 2022. Published by Igor Sikorsky Kyiv Polytechnic Institute. This is an Open Access article distributed under the terms of the licence CC BY 4.0 
As stated by Kahraman (2009), whether or not to utilize the mother tongue in the EFL classes is a rather challenging issue and there are various studies in the literature that both advocate and criticize utilizing mother tongue for teaching English. Some of the researchers suggest that limited amount of mother tongue can be utilized as essential pedagogical tool (Cook, 2001; de la Colina \& Mayo, 2009; Kahraman, 2009), While others assert that use of L1 has detrimental effects of second language learning process (Sarıçoban, 2010; Turnbull, 2001). Those who are against use of L1 explain their major reason as the risk of creating mother tongue (L1) dependence and thus preventing students from comprehensible input and context. Accordingly, Ellis (1994) claims that FL teachers' excessive uses of mother tongue shut off learners from comprehensible L2 input. (As cited in Sarıçoban, 2010, p.175). On the contrary, Cook (2001) supports that mother tongue should be integrated for teaching English claiming mother tongueis useful in explaining the grammar of the target language (TL) and also it is an effective tool for students to learn new vocabulary. While there is still no consensus on whether mother tongue will be allowed in foreign language classes, its practical profits need to be taken into account. Considering that even researchers cannot agree on the issue, English teachers concern about the appropriate and acceptable amount of use of L1 in their classes are based on reasonable grounds. Because excessive use of L1 have a detrimental effect for the target language (TL) teaching while it assumed to be useful in explaining and grammar rules, teaching vocabulary more effectively and time saving for giving instructions. Accordingly, Turnbull (2001) states that learner's L1 and L2 can coexist and "the L1 can save time inthe SL or FL classroom. ... It is efficient to make a quick switch to the L1 to ensurethat students understand a difficult grammar concept or an unknown word" (p. 208). Given the fact that teachers are either favor for or against use of mother tongue in English language classes, there have been inadequate studies reflecting teachers' opinions working in different education levels in compulsory education institutions.

Therefore, the study aims to examine whether there is a significant difference between the opinions of teachers working at particular education levels on utilizing L1 in English lessons.

\section{THEORETICAL BACKGROUND}

As Kahraman (2009) states, there is a near consensus among language educators that the use of mother tongue could be rather valuable source for both parties of education (teachers and learners). While Carless (2008) reflects it as "humanistic and learner-centered strategy, with potential to support student learning, but at the same time involving a risk of failing to encourage TL practice and communication" (p. 336).

So as to gain a perspective on the issue from the teachers' point of view, Kaymakamoğlu and Y1ltanlilar (2019) explored 5 non-native English teachers' perspectives on mother tongue (Turkish) use while teaching English in the English Preparatory School context of European University of Lefke in the Turkish Republic of Northern Cyprus (TRNC). The findings of the study indicated that the teachers had neutral points of view for utilizing Turkish in their EFL classes and underscored a place for Turkish (L1) in English (L2) classrooms.

Similarly, Copland and Neokleous (2011) investigated perceptions of four teachers who are working at two after-school private language institutions through classroom observations and interviews. Resultsof the interviews with the teachers reveal that all of the participants are opponents of the utilizing of L1 in EFL classes, yet teachers use it excessively in their classes. Besides, data obtained from classroom observations indicate that a number of L1 functions are identified and teachers utilize L1 for the specific function. Depending on the results both qualitative data, it was concluded that that there are contradictions between the actions and beliefs of the teachers because bilingual teachers have a sense of guilt when they teach target langue through their mother tongue.

In similar vein, Polio and Duff (1994) set out to explore when and for what functions teachers used the mother tongue of the students. In their study, data collected though classroom observations and interviews 13 language classroom instructors. Researchers found out that the teachers used L1 of the students for, from the most common to the least, vocabulary teaching was the most common 
use and lack of comprehension was the least common. Crawford (2004) investigated attitudes and use of target language of the 581 teachers in Australia. The study employed quantitative research design and data collected through a questionnaire. Statements was measured on a 6-point Likert scale with 1 "strongly agree" and 6 indicating "strongly disagree". Analysis of the quantitative data reflects that any teachers continue to make extensive use of the learners "L1 while they doubt or even actively oppose it' (p. 10). Ramos (2005) explored 5 Spanish teachers' perceptions on the use of mother tongue whether L1 is beneficial for the students' acquisition of second language and if the teachers 'opinions shift and whether it is affected by the teachers use of mother tongue. The study adopted mixed research method that qualitative data obtained though semi structured interviews while a questionnaire administered for the quantitative data. Findings of the study reveal that the teachers favor the use of mother tongue and their support for it increased.

According to Johnson (1994), teachers' beliefs influence their judgment and perception, the activities they prefer in the classroom, and it could promote to the development of teaching practices and teacher education programs. Therefore, this study is significant for two main reasons. First, it is intended to shed more lights by providing a source that includes the views of primary and high school teachers since previous studies included the views of teachers working with certain institution. However, this study will include the views of teachers who worked with primary and secondary levels in compulsory education institutions affiliated to the Ministry of National Education. Second, it will examine teachers' perceptions on the use of mother tongue with the language skills (reading, writing, speaking, and listening) in addition to grammar and vocabulary and therefore, it could be an important source for curriculum designers and material developers. Previous studies and discussions indicate conflicting findings and suggestions on L1 use in EFL classes. Therefore, the current study aims to answer the following research questions from the perspectives of EFL teachers' who work at primary and high schools on using Turkish as L1 in English language classrooms and seeks to answer following research questions:

1. Is mother tongue (L1) necessary in EFL classrooms?

a) For which language skill(s) should it be utilized?

b) What is the rationale for utilizing mother tongue?

2. Is there a significant difference between the perspectives of teachers who work at primary schools and high schools?

\section{METHODS}

This study took place in state schools of primary and high schools in the central and districts of Usak. Analysis of the data was conducted through both qualitative and quantitative research methods. A questionnaire developed by Kuru and Tekin (2019) was implemented to teachers working in the primary and high schools afflicted to the Ministry of National Education and semi structured interviews were conducted.

\subsection{Sample / Participants}

Two separate groups of participants took part in the study on a voluntary basis. The first group of participants comprised 30 non native English teachers working at state primary schools in the center and districts of Usak. Years of teaching experiences of the teachers vary between 5 to more than 25 years and, out of 30 participants, 27 were females and 3 were males which indicate that this group was dominated by the females with the rate of $90 \%$. The second group consisted of 30 nonnative English teachers and their years of teaching experience range from 1 to more than 25 years. Out of 30 teachers, who are working at high schools affiliated with the Ministry of National Education.

\subsection{Instrument(s)}

This study was carried out by following qualitative and quantitative means of investigation. Data collection tools are a questionnaire which was developed by Kuru and Tekin (2019), and semi structured interviews. The questionnaire comprised two parts that initial part of the questionnaire 
consists of demographic items, such as gender, years of teaching experience, rate of using L1, and current institution that teachers are working at while the second part of the questionnaire includes 16 items on a three-point Likert scale (disagree-neither agree nor disagree-agree). The questionnaire also consisted of two questions in the first section as to whether the Turkish language should be used or not and for which skills it should be utilized. The quantitative data were analyzed with a Statistical Package for Social Sciences 22 (SPSS). Additionally, to measure the internal-consistency of the instrument, a reliability analysis was conducted. Qualitative data collected through semi structured interviews and 8 primary and 8 high school teachers were interviewed to have a deeper insight into their views. Burgess (1984) identifies interviews as "conversation with purpose" (p. 102), and semi structured interviews lead the interviewer to find out distinctive topics needed to be covered, and it allows the development of unpredicted important areas (Mackey \& Gass, 2012). Participants are given pseudonyms to provide confidentially and they will be randomly selected on a voluntary basis. Thus, the study analyzed teachers' perspectives on who teach English as a foreign language (EFL) both qualitatively and quantitatively.

\subsection{Data collection analysis}

Qualitative and quantitative data for the study were collected during the spring semester of the 2020-2021 academic term. The participants were informed about the aim of the study and were assured that all information would be kept confidential. The questionnaire was administered in English because it is assumed all the participants would not have language related problems. For overall reliability, coefficient alpha was calculated and Cronbach's alpha was measured as 87 for 16-item questionnaire. These results revealed that the items in a questionnaire were reliable. Findings of the questionnaire were analyzed by means of chi square test, while all of the semi structured interviews were transcribed and the responses of the participants were grouped into themes by the researcher in relation with research questions.

\section{RESULTS}

The research attempts to find out teachers' perspectives about L1 use. To this end, a questionnaire which explores use of mother tongue in EFL classes has been employed for 30 primary school teachers and 30 high school teachers. The descriptive findings of the question 1 and 2 in the questionnaire seeking an answer to the 1st research question are presented in Table 1 below.

Table 1. Results of the Primary school and the High School teachers about their Perspectives on the Use of the mother tongue (L1) in EFL classes

\begin{tabular}{lllll}
\hline $\begin{array}{l}\text { 1. Do you think Turkish } \\
\text { should be used in English Yes \% }\end{array}$ & F & No \% & F \\
courses? & & & & \\
& 63.3 & 19 & 36,7 & 11 \\
Primary school teachers & 83.3 & 25 & 16.7 & 5 \\
High school teachers & 83.7
\end{tabular}

2.If your answer to the above question is yes, which of the English language skills do you think will be more useful to teach Turkish? (You can mark more than one item).

$\begin{array}{llllll}\text { Options } & \begin{array}{l}\text { Primary } \\ \text { teachers } \%\end{array} & \text { school } & \text { F } & \begin{array}{l}\text { High } \\ \text { teachers }\end{array} & \text { school } \\ \text { Grammar } & 57.8 & 11 & 68 & \\ \text { Vocabulary } & 73.6 & 14 & 52 & 17 \\ \text { Reading } & 21 & 4 & 28 & 7 \\ \text { Speaking } & 26.3 & 5 & 16 & 4 \\ \text { Listening } & 21 & 4 & 20 & 5 \\ \text { Writing } & 15.7 & 3 & 16 & 4\end{array}$

* 19 primary and 25 high school teachers responded second question. 
In response to first research question Table 1 is presented. Majority of the participants in both groups support use of mother tongue (L1) in English courses. Responses of the participants in both groups to question 1 indicate that the number of participants who thought Turkish should be utilized in English courses was quite higher than those who didn't advocate. Great majority of the high school teachers ( $f=25 / 83 \%)$ and more than half of the primary school teachers $(f=19 / 63 \%)$ supported that mother tongue (L1) should be used in English courses; referring that there was a tendency among participants of the both groups to use the mother tongue in English courses.

In addition to indicating overall tendency of the primary school and high school teachers to utilizing L1 in EFL classes, Table 1 also reveals preferences of the both groups regarding language skills. Although they have varying views on the benefit of L1 for different language skills in English courses, they all agree that utilizing is effective for improving specific language skills. The responses given to Q1 supported this quantitative data as in the following:

Table 2. Use of $\mathbf{L} 1$

\begin{tabular}{llll}
\hline Codes & Extracts & Themes \\
\hline Reasons & T1 "it should be allowed to some extent. L1 is also a source for & Tool & for \\
for using & language learners". & teaching \\
L1 & &
\end{tabular}

T3 "it is necessary to teach the details of the topic".

T 11 "Because the difficult topics can be very hard for students if we speak English".

T10 "It sometimes allows us to express ourselves better".

Expressing themselves better

T16 "It helps to save time and prevents misunderstanding".
Time saving

*Participants are given pseudonyms.

Second question which allows the participants to mark more than one option shows that the majority of the high school teachers ( $\mathrm{f}=17 / 68 \%$ ), and more than half of the primary school teachers ( $\mathrm{f}=11 / 57.8 \%)$ support that the use of $\mathrm{L} 1$ is more useful when teaching grammar than other English language skills. It is clear that both groups of teachers have the similar tendency regarding use of mother tongue for grammar teaching.

Second remarkable preference of the both groups of teachers is vocabulary. Majority of the primary school teachers $(\mathrm{f}=14 / 73.6 \%)$ and a little more than half of the high school teachers $(\mathrm{f}=13 / 52 \%)$ thought that $\mathrm{L} 1$ is effective when teaching vocabulary in EFL classes.

Additionally, speaking skill is ranked $3^{\text {rd }}$ among primary school teachers $(f=5 / 26.3 \%)$, in contrast to high school teachers $(\mathrm{f}=7 / 28 \%)$, who preferred reading. However, for the listening skills primary school teachers $(f=4 / 21 \%)$ and high school teachers $(f=5 / 20 \%)$ have similar rates. Writing skill is the least marked option in the questionnaire for the primary school teachers $(\mathrm{f}=3 / 15 \%)$ while speaking and writing had similar ratio $(\mathrm{f}=4 / 16 \%)$ for the high school teachers. It can be concluded that both primary and high school teachers' perceptions for the most marked two language skills are similar in terms of necessity regarding the use of the mother tongue, but there are differences in their preferences for the other language skills.

\section{Research question 1. B) What is the rationale for utilizing mother tongue?}

The research question 1. b) explored primary and high school teachers' intentions and the high perspectives about the reasons for their use of Turkish in EFL classes. The results pointed out that both the primary and the high teachers reflected a sign of positive tendency to use Turkish in 
English courses; however, differences arise between the perspectives of the two groups (see Table 3 and Table 4).

Table 3. Descriptive Statistics of the High School Teachers' opinions on the use of Turkish in EFL classrooms

Items
Agree

(F)
Disagree

(F)

\section{Neither \\ agree nor \\ disagree}

(F)

\begin{tabular}{|c|c|c|c|}
\hline $\begin{array}{l}\text { My students can ask for help in areas that are more easily to } \\
\text { understand by using Turkish. }\end{array}$ & 70 & 10 & 20 \\
\hline $\begin{array}{l}\text { I can better explain the similarities and differences between } \\
\text { Turkish and English by using Turkish. }\end{array}$ & 56.7 & 10 & 33.3 \\
\hline I can better explain complicated subjects by using Turkish. & 90 & 6.7 & 3.3 \\
\hline I can make a joke more easily by using Turkish. & 56.7 & 30 & 13.3 \\
\hline I can better communicate with my students by using Turkish. & 50 & 26.7 & 23.3 \\
\hline I can better maintain classroom discipline by using Turkish. & 40 & 43.3 & 16.7 \\
\hline I can explain the course content better by using Turkish. & 43.3 & 43.3 & 13.4 \\
\hline $\begin{array}{l}\text { I can check whether my students understand the content more } \\
\text { easily by using Turkish. }\end{array}$ & 40 & 36.7 & 23.3 \\
\hline $\begin{array}{l}\text { I can better explain what students need to do about the course } \\
\text { by using Turkish. }\end{array}$ & 43.3 & 30 & 26.7 \\
\hline $\begin{array}{l}\text { When I lecture in Turkish, my students are able to follow the } \\
\text { course better. }\end{array}$ & 53.3 & 16.7 & 30 \\
\hline $\begin{array}{l}\text { I can use my body language (gestures and facial expressions) } \\
\text { more effectively when speaking in Turkish. }\end{array}$ & 23.3 & 53.4 & 23.3 \\
\hline $\begin{array}{l}\text { When I use Turkish, my students will show more interest in } \\
\text { the English course. }\end{array}$ & 26.7 & 26.7 & 46.6 \\
\hline $\begin{array}{l}\text { Supportive and encouraging Turkish expressions such as well } \\
\text { done, super and great will get my students more motivated. }\end{array}$ & 30 & 40 & 30 \\
\hline $\begin{array}{l}\text { My students can carry out more effective work by using } \\
\text { Turkish in pair and group work. }\end{array}$ & 43.4 & 33.3 & 23.3 \\
\hline $\begin{array}{l}\text { My students can carry out more effective work by using } \\
\text { Turkish in pair and group work. }\end{array}$ & 10 & 63.4 & 26.6 \\
\hline $\begin{array}{l}\text { Allowing the use of Turkish will make the English course } \\
\text { more fun. }\end{array}$ & 30 & 43.4 & 26.6 \\
\hline
\end{tabular}

Table 3 illustrates the high school teachers' perspectives on the use of Turkish. It also shows the general trend of the use of Turkish EFL classes. As can be clearly indicated, "I can better explain complicated subjects by using Turkish." constituted the most frequent justification for the high school teachers' use of Turkish overall (90\%). Furthermore, "My students can ask for help in areas that are more easily to understand by using Turkish." (70\%), "I can better explain the similarities and differences between Turkish and English by using Turkish." (56\%), "I can make a joke more easily by using Turkish." (56\%) are among the most common reasons behind use of mother tongue for the high school teachers. On the other hand, "My students can carry out more effective work by using Turkish in pair and group work." (10\%) is least common reason for utilizing Turkish in EFL classes. 
Table 4. Descriptive Statistics of the Primary School Teachers' opinions on the use of Turkish in EFL classrooms

\begin{tabular}{|c|c|c|c|}
\hline Items & $\begin{array}{l}\text { Agree } \\
(\mathrm{F})\end{array}$ & $\begin{array}{l}\text { Disagree } \\
(\mathrm{F})\end{array}$ & $\begin{array}{l}\text { Neither } \\
\text { agree nor } \\
\text { disagree } \\
\text { (F) }\end{array}$ \\
\hline $\begin{array}{l}\text { My students can ask for help in areas that are more easily to } \\
\text { understand by using Turkish. }\end{array}$ & 66.7 & 3.3 & 30 \\
\hline $\begin{array}{l}\text { I can better explain the similarities and differences between } \\
\text { Turkish and English by using Turkish. }\end{array}$ & 56.7 & 10 & 33.3 \\
\hline I can better explain complicated subjects by using Turkish. & 66.7 & 10 & 23.3 \\
\hline I can make a joke more easily by using Turkish. & 63.3 & 10 & 26.7 \\
\hline I can better communicate with my students by using Turkish. & 56.7 & 16.6 & 26.7 \\
\hline I can better maintain classroom discipline by using Turkish. & 30 & 33.3 & 36.7 \\
\hline I can explain the course content better by using Turkish. & 43.3 & 23.4 & 33.3 \\
\hline $\begin{array}{l}\text { I can check whether my students understand the content more } \\
\text { easily by using Turkish. }\end{array}$ & 46.6 & 26.7 & 26.7 \\
\hline $\begin{array}{l}\text { I can better explain what students need to do about the course } \\
\text { by using Turkish. }\end{array}$ & 33.3 & 26.7 & 40 \\
\hline $\begin{array}{l}\text { When I lecture in Turkish, my students are able to follow the } \\
\text { course better. }\end{array}$ & 63.4 & 16.6 & 20 \\
\hline $\begin{array}{l}\text { I can use my body language (gestures and facial expressions) } \\
\text { more effectively when speaking in Turkish. }\end{array}$ & 30 & 50 & 20 \\
\hline $\begin{array}{l}\text { When I use Turkish, my students will show more interest in } \\
\text { the English course. }\end{array}$ & 33.3 & 23.3 & 43.4 \\
\hline $\begin{array}{l}\text { Supportive and encouraging Turkish expressions such as well } \\
\text { done, super and great will get my students more motivated. }\end{array}$ & 60 & 13.3 & 26.7 \\
\hline $\begin{array}{l}\text { My students can carry out more effective work by using } \\
\text { Turkish in pair and group work. }\end{array}$ & 53.4 & 33.3 & 13.3 \\
\hline $\begin{array}{l}\text { My students can carry out more effective work by using } \\
\text { Turkish in pair and group work. }\end{array}$ & 23.3 & 40 & 36.7 \\
\hline $\begin{array}{l}\text { Allowing the use of Turkish will make the English course } \\
\text { more fun. }\end{array}$ & 26.7 & 26.7 & 46.6 \\
\hline
\end{tabular}

As clearly seen in the Table 4 the most common statement that primary school teachers preferred is "My students can ask for help in areas that are more easily to understand by using Turkish." (66.7) and the most common reason for their use of L1 is "explaining complicated subjects by using Turkish." (66.7). However, these statements are not the mostly preferred statements by the high school teachers. While the least common statement that the primary school teachers mentioned is "My students can carry out more effective work by using Turkish in pair and group work." (23.3), it wasn't among the high school teachers' least favorite statement. It could be concluded from the findings that there are differences between the perspectives of the high school and primary school teachers in terms of the justifications they provide for the use of L1 in EFL classes.

Research question 2: Is there a significant difference between the perspectives of teachers who work at primary and high schools?

Second research question intended to figure out whether there is a statistically significant difference between the perception of primary and the high school teachers on using Turkish in English courses. Additionally, it indicates both groups of teachers' perceptions on the use mother tongue. It also illustrates general tendency of for utilizing L1 in English courses Therefore, Table 5 presents descriptive statistics of the both groups. 


\begin{tabular}{|c|c|c|c|c|c|c|c|}
\hline Items & Agree & Disagree & $\begin{array}{l}\text { Neither } \\
\text { agree nor } \\
\text { disagree }\end{array}$ & Agree & Disagree & $\begin{array}{l}\text { Neither } \\
\text { agree nor } \\
\text { disagree }\end{array}$ & $\mathrm{P}$ \\
\hline 3 & 70 & 10 & 20 & 66.7 & 3.3 & 30 & $>0.005$ \\
\hline 4 & 56.7 & 10 & 33.3 & 56.7 & 10 & 33.3 & $>0.005$ \\
\hline 5 & 90 & 6.7 & 3.3 & 66.7 & 10 & 23.3 & $>0.005$ \\
\hline 6 & 56.7 & 30 & 13.3 & 63.3 & 10 & 26.7 & $>0.005$ \\
\hline 7 & 50 & 26.7 & 23.3 & 56.7 & 16.7 & 26.6 & $>0.005$ \\
\hline 8 & 40 & 43.3 & 16.7 & 30 & 33.3 & 36.7 & $>0.005$ \\
\hline 9 & 43.3 & 43.3 & 13.4 & 43.3 & 23.4 & 33.3 & $>0.005$ \\
\hline 10 & 40 & 36.7 & 23.3 & 46.6 & 26.7 & 26.7 & $>0.005$ \\
\hline 11 & 43.3 & 30 & 26.7 & 33.3 & 26.7 & 40 & $>0.005$ \\
\hline 12 & 53.3 & 16.7 & 30 & 63.3 & 16.7 & 20 & $>0.005$ \\
\hline 13 & 23.3 & 53.4 & 23.3 & 30 & 50 & 20 & $>0.005$ \\
\hline 14 & 26.7 & 26.7 & 46.6 & 33.3 & 23.3 & 43.4 & $>0.005$ \\
\hline 15 & 30 & 40 & 30 & 60 & 13.3 & 26.7 & 0.029 \\
\hline 16 & 43.4 & 33.3 & 23.3 & 53.4 & 33.3 & 13.3 & $>0.005$ \\
\hline 17 & 10 & 63.4 & 26.6 & 23.3 & 40 & 36.7 & $>0.005$ \\
\hline 18 & 30 & 43.4 & 26.6 & 26.7 & 26.7 & 46.6 & $>0.005$ \\
\hline
\end{tabular}

\section{High school teachers (Frequency, \%) Primary school teachers (Frequency, \%)}

According to the chi-square test results in Table 5, there was no significant difference between the perceptions of the primary and high school teacher candidates $(p>0.005)$ with regards to the use of Turkish in English courses. A significant difference was only found $(p=0.029)$ for the statement 15 referring a difference between the perspectives of the primary and high school teachers. Qualitative supporting data presented though Table 6.

Table 6. Themes of teachers' perceptions for use of L1

Codes
Extracts of L1 "When students are in primary school it means they are in
beginner level. In my opinion it's hard to teach students
grammar when they are in beginning level. Because when I
teach grammar, I need to talk fluent and maybe I can use some
words they don't understand and it can be complex and too hard
to understand for them. Therefore, I need to use some L1 when I
teach grammar".
T13 "Grammatical structures should exactly be taught via L1.
Students do not need to focus on the meaning; instead, they
work on the structure, if we give them in L1. They also have the
chance to compare and contrast with their L1 to reach an
understanding".
T6 "If the learners have prejudice about learning a foreign
language, then I can use L1 to motivate him/her".
T2 "My reasons are not to cause students feel afraid of learning
English and try to complete the curriculum before the term ends.
Moreover, sometimes some tests are applied to students, and this
also requires using L1 to be able make students get prepared for
those tests".

Themes

Teaching grammar

*T2, T10 are primary school teachers

*T6, T13 are high school teachers 


\section{DISCUSSION}

While there is still debate over whether to allow L1 in foreign language classes, its effect and practical benefits shouldn't be ignored. Schweers (1999) supports the use of L1 with the quote "starting with the L1 provides a sense of security and validates the learners" experiences and leading them to express themselves. In the similar vein of thought, the study set out to shed light on the perspectives of primary and high school teachers' perspectives on using mother tongue in EFL classes. Findings obtained from the quantitative data suggest that the great majority of both primary $(63.3 \%)$ and high school teachers $(83.3 \%)$ favor use of the mother tongue. The results are consistent with the previous studies (Ramos, 2005; Crawford, 2004; Pan, Yi-chun, \& Pan, Yi-ching, 2010) in terms of teachers' perceptions on the use of L1.

Qualitative and quantitative data also reveal that more than half of the teachers working in each institution (primary school and high school) highlighted the necessity of using the mother tongue while teaching grammar. Similarly, Kayaoglu (2012) conducted the research with 44 instructors working at a state university to explore their perceptions of using the mother tongue in ELF classes. The result of the study is similar in terms of attitudes towards using mother tongue for grammar teaching. Additionally, the results revealed that primary school teachers $(73.6 \%)$ have more positive attitudes towards using L1 for vocabulary than the high school teachers $(52 \%)$ in English courses. Polio and Duff (1994) explored when and for what purposes teachers use L1 in the classes. Mother tongue is utilized by the participants of the study for the vocabulary which was the most common use. Atkins and Varantola (1997); Laufer and Kimmel (1997) also supported the use of L1 for teaching vocabulary. In similar vein, Thornbury (2002) hinted mother tongue for vocabulary as the immediate tool for the meaning of words. However, utilizing L1 for L2 vocabulary is criticized by Nation (2003). It could be concluded from the study that there was a consensus among the teachers on the use of mother tongue for the teaching of grammar and vocabulary while there is a mismatch between the primary and high school teachers' rates of remarking speaking, listening, and reading are better taught by allowing Turkish in EFL classrooms. Besides, the use of mother tongue for writing is not regarded as beneficial as other language skills by the both groups of teachers. On the other hand, the result is not aligned with the findings obtained from Schweers (1999) and Nation (2003) which indicated that the use of L1 for writing had effective results for improving learners' writing skills.

To conclude, the results of the study showed that the primary school and the high school teachers use Turkish depending on the grounds such as teaching grammar concepts, vocabulary and instructions, and their perspectives tend to differ for the other language skills as the rationale for using mother tongue in EFL classes. One of the justifications behind this might be students' age, as in the primary schools, learners are relatively younger compared to high schools implying age factor which plays a significant role in second language teaching/ learning situations (Cook, 1985). The findings could be vital for both primary school and high school teachers, material developers, and curriculum designers in terms of integration of mother tongue for instructional goals, materials and learning settings.

\section{CONCLUSIONS AND SCOPE FOR THE FURTHER RESEARCH}

The current research investigated teachers' perceptions on the use of first language in EFL classes. It also attempted to determine any statistically significant differences between primary and high school teachers working in state schools. Furthermore, the study found out the justifications for L1 use among participants towards the use of L1 in their classes. The findings of the study reveal that EFL teachers had highly positive perspectives on the use of L1 when it intended to facilitate English.

The results showed that the primary school and high school teachers remarked various justifications for utilizing mother tongue in their English classes, and the majority of both primary and high school teachers share the opinion that the use of Turkish is an indispensible part of their teaching in EFL context. The findings also revealed that the reasons for primary school and high school teachers' use of L1 are similar. To sum up, the majority of teacher candidates regarded using 
Turkish when teaching English grammar and vocabulary skills as the most beneficial and use of L1 is not necessary for the writing skill while their points of view varied for the speaking and listening skills.

The present study is of vital importance for contributing to the long-standing issue among scholars in the area of language teaching with regard to use of L1 in EFL classes through exploring perceptions of teachers. As the place of L1 is a relatively disputable matter in English courses and studies investigating the similarities and differences of the teachers who work at different education levels is inadequate therefore, neglected field of study needs further research. Besides, there is not much comparative study on the use of L1 by primary school and high school teachers reflecting different levels of the program. Depending on the previous studies on the use of mother tongue, L1 could be beneficial for clarifying unfamiliar vocabulary and grammar. It could be concluded that investigating ways to mediate between English and Turkish in EFL context and integrate the materials in the learning environment contribute to certain degree to fulfilling the needs of diverse students.

We see the scope of further research in this direction in the study of the peculiarities of the influence of the native language in English classes on the development of language skills of Turkish high school students.

\section{REFERENCES}

Atkins, B. T., \& Varantola, K. (1997). Monitoring dictionary use. International Journal of Lexicography, 10(1), 1-45. Bloomfield, L. (1956). Language. New York: Henry Holt and Company, Inc.

Burgess, R. G. (1984). In the field. London: Allen \& Unwin.

Carless, D. (2008). Student use of the mother tongue in the task-based classroom. ELT Journal, 62(4), 331-338. https://doi.org/10.1093/elt/ccm090

Çelik, S. (2008). Opening the door: An examination of mother tongue use in foreign language classrooms [Yabancı dil sınıflarında ana dil kullanımının incelenmesi]. Hacettepe Üniversitesi Eğitim Fakültesi Dergisi (H. U. Journal of Education), 34, 75-85. [in Turkish]

Cook, V. (1985). Chomsky's universal grammar and second language learning. Applied linguistics, 6(1), 2-18.

Cook, V. (2001). Using the first language in the classroom. The Canadian Modern Language Review, 57(3), $402-423$.

Copland, F., \& Neokleous, G. (2010). L1 to teach L2: Complexities and contradictions. ELT Journal, 65(3), $270-280$.

Crandall, J. A. (2000). Language teacher education. Annual Review of Applied Linguistics, 20, 34-55. https://doi.org/10.1017/S0267190500200032

De la Colina, A. A., \& Mayo, M. D. P. G. (2009). Oral interaction in task-based EFL learning: The use of L1 as a cognitive tool. IRAL, 47, 325-345. https://doi.org/10.151/iral.2009.014

Ellis, R. (1994). The Study of Second Language Acquisition. New York: Oxford UniversityPress.

Johnson, K. E. (1994). The emerging beliefs and instructional practices of pre- service English as a second language teachers. Teaching and Teacher Education, 10, 439-452.

Kahraman, A. (2009). The role of the mother tongue in fostering affective factors in ELT classrooms. Journal of English as an International Language, 5, 107-128.

Kayaoğlu, M. N. (2012). The use of mother tongue in foreign language teaching from teachers' practice and perspective. Pamukkale Üniversitesi Ë̆itim Fakültesi Dergisi, 32(2), 25-35.

Kaymakamoğlu, S. \& Y1ltanlılar, A. (2019). Non-native English teachers' perceptions about using Turkish (L1) in EFL classrooms: A case study. International Online Journal of Education and Teaching (IOJET), 6(2), 327-337.

Kuru, M. E., \& Tekin, M. (2019). A Comparative Study on the Perspectives of ELT Teacher Candidates and Vocational High School Students on L1 Use in English Classrooms. International Association of Research in Foreign Language Education and Applied Linguistics ELT Research Journal, 8(1), 42-63.

Laufer, B., \& Kimmel, M. (1997). Bilingualised dictionaries: How learners really use them. System, 25(3), 361-369.

Mackey, A., \& Gass, S. M. (2012). Research Methods in Second Language Acquisition: A Practical Guide. In Research Methods in Second Language Acquisition: A Practical Guide. https://doi.org/10.1002/9781444347340

Nation, P. (2003). The role of the first language in foreign language learning. Asian EFL Journal, 5(2). Retrieved from http://www.asian-efljournal.com

Pan, Yi-chun, \& Pan, Yi-ching. (2010). The Use of L1 in the Foreign Language Classroom. Colombian Applied Linguistics Journal, 12(2), 87-96. https://doi.org/10.14483/22487085.85

Polio, C. G., \& Duff, P. A. (1994). Teachers' language use in university foreign language classrooms: A qualitative analysis of English and target language alternation. Modern Language Journal, 78 (3), 313-24.

Ramos, F. (2005). Spanish teachers 'opinions about the use of Spanish in mainstream English classrooms before and after their first year in California. Bilingual Research Journal, 29(2), 411-433.

Sarıçoban, A. (2010). Should native languages be allowed in foreign language classes? Eurasian Journal of Educational Research, 38, 164-178. 
Schweers, C. W. Jr. (1999). Using L1 in the L2 Classroom. English Teaching Forum, 37(2), 6-9.

Thornbury, S. (2002). How to teach vocabulary. Pearson Education Limited.

Turnbull, M. (2001). There is a role for the L1 in second and foreign language teaching, but... The Canadian Modern Language Review, 57(4), 531-540.

Ділек Дурукан, Айхан Кахраман. Уявлення турецьких учителів щодо використання рідної мови на заняттях 3 англійської мови. У статті висвітлено результати дослідження думок турецьких учителів національної початкової та старшої середньої школи щодо використання рідної мови на уроках з іноземної мови. Наголошено, що досліджувана проблема постійно перебуває у полі зору дослідників і дотепер немає єдиної думки щодо цього спірного питання. Зазначено, що більшість таких досліджень у Туреччини проводяться на рівні закладів вищої освіти, а на початковому та середньому шкільних рівнях їх кількість $є$ незначною. У статті також окреслено загальну думку турецьких учителів щодо ефективності використання рідної турецької мови на уроках 3 англійської мови з метою розвитку певних мовних навичок учнів. Загалом 30 вчителів початкової та 30 старших класів, які працюють в Усаку, взяли участь у дослідженні добровільно. У дослідженні використовувався змішаний метод, а дані були зібрані на основі анкетування, розробленого Куру і Текіним. Задля отримання якісних даних були проведені напівструктуровані інтерв'ю з випадково відібраними вчителями початкової школи (8) та старших класів (8). За допомогою статистичного пакету для соціальних наук проводилась описова статистика та проаналізовано якісні дані. Результати кількісних даних засвідчили, що більшість турецьких учителів початкової та старшої школи підтримують використання рідної мови на заняттях 3 англійської мови як іноземної. Встановлено, що немає суттєвої різниці між уявленнями вчителів початкової та старшої школи щодо використання рідної мови на уроках 3 англійської мови. Результати якісних даних підтверджують висновки кількісних даних.

Ключові слова: рідна мова; вчителі початкових класів; вчителі середньої школи; сприйняття; напівструктуровані інтерв'ю. 